\section{Canadian Scholarly Journal Publishing: The Knowledge Economy Calls}

Rowland Lorimer

Simon Fraser University
VOLUME 11 / ISSUE 2 / 2020

\begin{abstract}
Background The vast opportunities that digital realities present in cultural and information industries have not been fully embraced by Canadian scholarly journal publishing and attendant policy.

Analysis In Canada, the journal support programs that currently exist are minimal, dated, and do not encourage the development of a vibrant publishing sub-sector. A review of the evolution of Canadian government programs for book and magazine publishing underlines the achievements of government support for these sectors and the benefits they bring to Canada.
\end{abstract}

Conclusion and implications Parallel support focused on emerging digital prospects in journal publishing, rather than editing and accessibility, would help pave the way for increased Canadian development in the quickly expanding knowledge economy.

Keywords Journal publishing; Publishing policy; Open access; Knowledge economy; Digital publishing; Human betterment; Net-zero growth

\section{Résumé}

Contexte Lédition de revues savantes au Canada et les politiques qui s'y rattachent n’ont pas entièrement profité des grandes occasions que représentent les réalités numériques des industries de la culture et de l'information.

Analyse Au Canada, les programmes actuels d'appui aux revues sont rudimentaires et périmés. Ils n'encouragent pas le développement d'un sous-secteur dynamique dans le

CISP Press

Scholarly and Research Communication

Volume 11, Issue 2, Article ID 0206361, 17 pages

Journal URL: www.src-online.ca doi: 10.22230/src.2020v11n2a361

Received June 12, 2020, Accepted July 9, 2020, Published July 16, 2020

Lorimer, Rowland. (2020). Canadian Scholarly Journal Publishing: The Knowledge Economy Calls. Scholarly and Research Communication, 11(2): 0206361, 17 pp.

(c) 2020 Rowland Lorimer. This Open Access article is distributed under the terms of the Creative Commons Attribution Non-Commercial License (http://creativecommons.org/licenses/by-nc-nd/2.5 $/ \mathrm{ca}$ ), which permits unrestricted non-commercial use, distribution, and reproduction in any medium, provided the original work is properly cited.
Rowland Lorimer is the Founding Editor of Scholarly and Research Communication and Professor Emeritus at the CISP Journal Services, Simon Fraser University, Vancouver, BC.Email: lorimer@sfu.ca 


\section{Scholarly and Research}

\section{Communication}

VOLUME 11 / ISSUE 2 / 2020 monde de l'édition. Un recensement de lévolution des programmes du gouvernement canadien pour l'édition de livres et de magazines souligne cependant les

accomplissements de l'appui gouvernemental pour ces secteurs et les bénéfices que cet appui apporte au Canada.

Conclusion et implications Plutôt qu'un appui axé sur la révision ou l'accès, c'est un appui parallèle portant sur les nouvelles possibilités numériques de lédition des revues savantes qui accroîtrait au Canada le développement de léconomie du savoir en pleine expansion.

Mots clés Édition de revues; Politiques concernant l'édition; Libre accès; Économie du savoir; Édition numérique; Amélioration de l'humanité; Croissance zéro

\section{Introduction}

The twenty-first century offers humanity a developing electronic information environment that, as Marshall McLuhan sensed, is vast in its influence. Understanding how Canada can best take advantage of the digital environment requires an assessment of past communication patterns and structures and how they have, or have not, been addressed. This exploration focuses on Canada's research journals and how they might be strengthened to take full advantage of Canada's investment in research and capture the emerging opportunities that are arising from the development of a knowledge economy.

Preceding and following Confederation in 1867, the various sectors of Canadian publishing have struggled to establish and sustain themselves in competition with larger foreign-based industries: British and French publishing on the one hand and American publishing on the other. As of 2020, an established national English language publishing industry shares the market with foreign firms, particularly U.S. and U.K. firms. A parallel establishment exists for Canadian French language publishing. To ensure sustainability, supportive government policies assist the Canadian sector. These policies parallel Canadian government support for other media, such as film, broadcasting, and popular music. In scholarly book and journal publishing, government policies support the publication of research; however, that support has not encouraged the development of professional expertise and stable, opportunity-seeking enterprises.

Given the development of information technology, an opportunity exists for Canada to build a digitally transformed, vibrant scholarly journal publishing sector parallel in achievement to the book and magazine sectors. In addition to strengthening journal publishing, Canada would gain three spin-off advantages: a cadre of entrepreneurs and workers with experience in a dynamic and creative information industry; an increase in Canada's international stature as a research-intensive, knowledge-producing economy staffed by home-grown talent; and an opportunity to participate in the development and operation of a climate-friendly, increasingly powerful and complex infrastructure intended to maximize the circulation of research, the social good, and human betterment.

\section{Canadian magazine publishing and attendant policy}

Similar to railways, magazines were key to building social cohesion in a nascent Canada, 
a contribution that was recognized early in Canada's history by the federal government. This recognition gave rise to postal subsidies (Canada, 1961), which reduced circulation costs throughout the vast geographical expanse of the country. Today, magazines drop packages of ideas off a virtual train that passes through Canadian homes courtesy of Canada Post and/or the electromagnetic spectrum. Many titles are also available at retail newsstands and other pick-up points scattered through urban and suburban areas.

The predominant barrier to maintaining that flow of ideas and interactions in Canada is not snow, sleet, hail, or even extreme cold and mountains. Rather, it is the size and organization of the Canadian market in comparison to that of the U.S. The diminutive stature of the Canadian market registers in the minds of Canadians as less vibrancy, less choice, and comparatively high prices. It registers in the work realities of producers as much more than fewer sales. Such a market creates comparative distribution inefficiencies, underdevelopment in the professions that contribute to the production of magazines, and, most importantly, a weakened domestic opportunity to encourage a discourse on Canadian affairs.

From the beginning, the Canadian magazine industry recognized a Sisyphean tilt to its playing field that could not be righted by postal subsidies, given their availability to all qualifying foreign and domestic magazines mailed in Canada. But as the decades went by, the reality of U.S.-based competitors amortizing editorial costs in their home market and exporting extended print-runs to Canada became a growing irritant. These run-on copies added both subscriptions fees and advertising revenue to their competitors' bottom lines. In the post-World War II era of a Western global rebuilding of democracy and an evolving consumerism unmatched in history, the attraction of lower prices for good-looking, vaguely familiar content that addressed North American social realities captured a significant percentage of Canadian magazine readers.

Canada's magazine industry presented this uneven playing field to government: Since editorial (original non-advertising content) was costly to them but already amortized for their U.S. competitors in their domestic market, the industry suggested tweaking Canadian income tax law to make the costs of advertising a tax deductible business expense only when it accompanied original Canadian content. In effect, this would double the costs of advertising in a foreign magazine being sold in Canada. The government considered this recommendation drafted legislation, and Section 19(1) of the Income Tax Act was amended by Bill C-58 in 1975 to encompass this change (Acheson \& Maule, 2000; Litvak \& Maule, 1980/1981). This policy was later undermined by the signing of the 1994 North American Free Trade Agreement.

The result of the 1975 amendment to income tax law? Not a boondoggle for domestic producers (the field was still not level) but rather the survival of a certain number of national magazines including Maclean's, a Canadian news magazine, and Saturday Night (1887-2005) a national general interest magazine. That survival translated into Canadian researchers, writers, editors, illustrators, photographers, art directors, ad salespeople, managers, and so forth gaining opportunities for the creation and presentation of Canadian information, entertainment, and ideas, and the establishment of a recognized profession. Readers gained access to that creativity and, as a result, gained a
Scholarly and Research Communication

VOLUME 11 / ISSUE 2 / 2020

The predominant barrier to maintaining a flow of ideas is market size.
The industry suggested tweaking income tax law. 
Scholarly and Research Communication

VOLUME 11 / ISSUE 2 / 2020 better understanding of their country and culture. The country gained an augmented level of national discourse.

\section{Canadian book publishing and attendant policy}

To a degree, the development of Canadian book publishing parallels the trajectory of Canadian magazines, but with a decade lag. Historically, the main way that book publishers amassed readers was to import the British empire's products and distribute them to the empire's local diaspora. Taking the common next step of substituting imports with domestic production was problematic, not because Canadian products were not of equal quality but because they were new and fundamentally different from those of the empire: They were written by Canadians for other Canadians, a national self-defining exercise.

Four development patterns emerged in book publishing. First, once a Canadian sales agent of a large publisher made obvious the nature and extent of the Canadian market for foreign-authored titles, U.K. publishers would often consolidate this business arrangement in parallel with business arrangements in other Commonwealth countries. Print runs for U.K. publishers became based on projected sales in domestic, European, and Commonwealth markets. A second, contrasting pattern emerged with respect to the largest U.S. publishers. They tended to see an agent-identified market as an opportunity to set up a Canadian subsidiary: a branch plant that served mainly as a distribution arm for U.S. product. The largest U.S. publishing companies followed this route, particularly in the 1960 s and 1970 s.

As the American book publishing industry strengthened, a third pattern emerged. U.S. companies began to acquire North American (U.S. and Canadian) rights for the republication of U.K. and other foreign-published titles. For such foreign titles, Canadian readers were served up the U.S. version via U.S.-owned branch plants. Ironically, the U.S. publishers also acquired rights to republish Canadian titles (for the U.S. market), some of which found their way back into the Canadian market, drawing off a certain percentage of the Canadian market from the originating publisher.

As the years went by, the position of Canadian publishers' agents, weakened. At best they found themselves working for smaller and smaller firms. The resulting financial constraints led to the suppression of what was a sideline operation for some Canadian agents: the origination and publication of titles written by and for Canadians. But by the 1970s, with the emergence of a new generation of book publishers intent on seeing Canadian books in Canadian bookstores, this "sideline" activity shed its cross-title financial underpinnings-Canadian titles financed by the profits of imported best-sellers-and turned into a fourth development pattern of publishing Canadian books on their own.

"Such is life," emerged as an acceptable justification to publishers' agents who were denied long-term financial benefits and managerial responsibility from the hard work of establishing a market presence for a foreign business. But by the 1970s, Canada's socio-political milieu had become sufficiently different that the passive acceptance of foreign dominance in publishing became unacceptable. Increasingly, a new generation 
of publishers effectively greeted, "Such is life," with a determined push-back: "No it's not!" With exposure to European graduate schools, creative institutes, and cultural politics, the new publishers, alongside other pre-boomers, had learned that there were myriad creative, meaningful, and life-affirming opportunities to be pursued made possible by governmental support.

As a result, in effect they transformed, "No it's not," into something akin to, "Government has the responsibility to structure the economy in the national interest rather than passively accept an evolved neocolonial political economy that denied Canadians the opportunity for self-expression" (see Association of Canadian Publishers 1980, 1985, 1991; see Lorimer, 2012, Chapter 3).

It was not as if the federal government was ignorant of the emerging realities of a twentieth-century nation. After a lengthy sojourn in the U.K., Vincent Massey, later to be the first Canadian-born Governor General, returned to Canada in 1946. In due course, Massey was charged with heading up a major Royal Commission on National Development in the Arts, Letters and Sciences (Canada, 1952) While, ironically, the report explicitly set aside publishing, the government acted on many of the commission's recommendations to develop cultural and knowledge institutions and support structures.

In the early 1970s, the creative sector, academe, and the publishing industry - including authors and newly established book publishers - joined Massey in calling for wholesale reform in the cultural, artistic, and research sectors of society and in particular, publishing and other cultural industries (Association of Canadian Publishers, 1980, 1985,1990 ). The position of the publishers was also facilitated and strengthened considerably by the groundbreaking Ontario Royal Commission on Book Publishing (Ontario, 1972). This text, and its informing Background Papers (Ontario, 1971), which were largely based on the expertise of the University of Toronto Press's Marsh Jeanneret, laid the groundwork for government intervention and specific methods of delivering effective support to Canada's book publishers.

The problem in moving forward with sound policy in book publishing was that, unlike magazine publishing, there was no costless quick fix parallel to Bill C-58. And so, the federal government dusted off the concept of arts grants and began to subsidize qualifying book titles through the Canada Council for the Arts (see Lorimer, 2012, Chapter 2). While adequate for arts projects, project grants were insufficient for ongoing publishing businesses where investment is required in the business as a whole to allow firms to carry the multiple titles that are forever in the works while others are freshly published.

So began a back and forth between provincial and federal governments and the publishing industry that, in 1986, finally resulted in an acceptable formula for supporting ongoing book publishing. It was based on business-oriented grants with sufficient resources and an adequate structure to address the needs of the heterogeneous collection of publishing houses in terms of size, location, and genre orientation. It allowed those publishers to mount and maintain publishing programs focused on Canadian literary talent and salient Canadian realities. Notably, the explicit aim of the program was

\section{Scholarly and Research}

\section{Communication}

VOLUME 11 / ISSUE 2 / 2020
The Massey

Commission and the groundbreaking Ontario Royal Commission on Book Publishing laid important ground work. 


\section{Scholarly and Research}

\section{Communication}

VOLUME 11 / ISSUE 2 / 2020

Canada's National

Research Council

(NRC) provided a

venue for Canadian

scientific research.

Humanities and social science journals were treated differently. the capture of overall market share by Canadian publishers, not subsidies to make titles possible or keep firms solvent (see Lorimer, 2012, Chapter 3). Complementary support was available for creative works from the Canada Council for the Arts.

Scholarly book publishers successfully inserted themselves into this government/publisher partnership. They obtained support via a supplementary project grant format that provided funds for scholarly researchers to flow through to Canadian publishers, both scholarly and general book publishers, to facilitate the publication of their research.

\section{Canadian scholarly journal publishing and attendant policy}

Scholarly journal publishers were treated differently by different governmental structures. The 1929 founding by Canada's National Research Council (NRC) of a single journal, the Canadian Journal of Research, provided a venue for Canadian scientific research (for both NRC and other researchers) to be shared nationally and internationally. The journal grew into a publishing department, and by 1951, NRC's one journal had split into six, focusing on medicine, physics, chemistry, botany, zoology, and technology, respectively. By 1970, it was publishing nine journals. The department continued to evolve and expand, and in 1988, the NRC's publishing department became NRC Research Journals. In 1994, it merged with NRC's Canada Institute for Scientific and Technical Information, acquired the Canadian Journal of Fisheries and Aquatic Sciences and a monograph program from the Department of Fisheries and Oceans, and was renamed NRC Research Press (NRC, 2009; VanBuskirk, 2009). In 2010, the press was spun off into a not-for-profit operation called Canadian Science Publishing (CSP) and the decision was made to suspend the monograph publishing program. Given this new lease on life, CSP went on to both acquire and launch new journal titles. As of 2020, CSP (2020a) was publishing 24 of its own titles and providing services for 14 more independently owned journals.

Humanities and social science journals were treated differently from scientific research journals. The Massey Commission recommended the funding of an arts, letters, and social science council (Canada, 1952). That body very quickly split into the Canada Council for the Arts (CCA) and the Social Science and Humanities Research Council of Canada (SSHRC). For years, SSHRC allocated some its administrative funding to journals to help cover costs and ensure publishing opportunities for Canadian scholars. This journal support, now called the Aid to Scholarly Journals program, was a spin-off of SSHRC's mandate to fund research.

The need of journals for continuous funding in stable amounts from year to year contrasted with the dynamics of SSHRC's normal modus operandi, which was to provide research project funds, not unlike arts grants. SSRHC's main activity was and is to run funding competitions and often uses rejection rates, sometimes more than 50 percent, as evidence of the demand for funds. Clearly, that level of grant failure would have made it impossible to maintain a stable set of publishing opportunities for Canadian humanities and social science researchers.

Unrelated to grant success rate but key to understanding the nature of journal support, SSHRC required the recipients of journal support, in the order of 130 -plus social sci-

Lorimer, Rowland. (2020). Canadian Scholarly Journal Publishing: The Knowledge Economy Calls. Scholarly and Research Communication, 11(2): 0206361, 17 pp. 
ences and humanities journals in recent years, to be not-for-profit operations. SSHRC was able to verify this status by requiring the annual submission of journals' financial reports. Also, SSHRC designated the journal editor as the grant recipient to ensure the funds were used to support the journal, not the society that owned the journal. While these controls met the fiduciary needs of SSHRC, by focusing on the academic journal editor - an academic subject-matter expert who often serves for a relatively short term - the program subsidized organized editing. Notably, unlike support provided to Canadian book and magazine publishers, SSHRC's journal support program did not consider or support the development of relatively robust publishing operations attentive to market opportunities, risk-taking, and development. Also, in contrast to Canada's science journals, with some exceptions, humanities and social science journals faced a relative absence of natural evolution within such overarching administrative entities as university presses.

\section{Uncelebrated success: An expanding and transforming global market for scholarly journals}

In North America and Europe following World War II, there was a dramatic expansion in journal markets. That expansion was brought about by vast increases in funded research activity and post-secondary education, complemented by the geopolitical supremacy of science, especially physics and chemistry. All libraries wanted access to the latest science, and, as publishing magnate Robert Maxwell (see Bower, 1989) proved to everyone, libraries had the resources, for a time, to pay any price.

With this vast expansion, journals found that they could increase their readerships from a captive audience of society members, or members of a discipline, to much larger, and quickly expanding, domestic and international library markets. In pursuit of international markets, gradually increasing numbers of major society-owned journals partnered with established large journal publishers and/or secondary aggregators to acquire cost-effective publishing services from organizations with market knowledge, a recognizable brand, and a global sales force. Others, and almost all smaller journals, continued to operate on their own.

There is little doubt that these developments increased international circulation and hence the attention to Canadian research. This post-war expansion represented a shift in the international communication of research from informal (free) exchanges of offprints by academics with their international colleagues to business activities by publishers in the form of sales to research libraries.

This global and national expansion of journal publishing continued into the 1980 os and successive decades, yet it was not widely lauded. The reasons for a lack of celebration included the following:

- The expansion was part of a general growth and refocusing of the post-war economy.

- Librarians in Canada and around the world were in the process of mounting a cri de coeur ruing what they called the "serials pricing crisis" (librarians refer to journals as serials; books are called monographs) describing what they saw as
VOLUME 11 / ISSUE 2 / 2020
Market expansion without praise. 


\section{Scholarly and Research}

\section{Communication}

VOLUME 11 / ISSUE 2 / 2020 unjustifiable, ever-increasing prices charged by the international journals. A discussion of the state of journal publishing in the 1990s can be found in "Scholarly Communication in the Next Millennium: Selected Papers from Canada's Policy Conference" (Canadian Journal of Communication, 1997).

- Canadian initiatives partnering with foreign multinationals often triggers nationalist regret.

The hidden element in this story was that the structure for SSHRC support was showing its age. As more journals increased their circulations by signing up with the large publishers to oversee their non-editorial operations, their lack of fit with SSHRC's journal support program was a growing concern. The fundamental not-for-profit aspect of the SSHRC's Aid to Scholarly Journals program was focused on editorial elements, that is to say, the peer certification of the value of the research reported and good writing. But with the vast expansion of journal titles and the opening of international markets, journals were finding it advantageous to maintain editorial control and to outsource non-academic "publishing services," such as production, marketing, sales and distribution, and associated brand enhancement, to for-profit commercial journal publishers. This bundle of services allowed them to maintain academic ownership but gave the commercial publishers control of the business side of the journals. Inevitably, acting outside the oversight of SSHRC, the contracted publishers priced journals to make them profitable and often to flow "royalties" back to the editorial office. Because most journals were arms of scholarly societies, the funds became society income.

As a result, SSHRC's ability to monitor whether journals were generating revenues beyond expenses was compromised. At times, SSHRC journal support funds were underwriting foreign commercial for-profit and not-for-profit publishers, and the nonjournal activities of scholarly societies.

While these money flows were not fraudulent, the dynamic gets somewhat dicey when a for-profit company controls the financials of a not-for-profit enterprise. In fairness, the SSHRC program was also problematic for journals owned and operated by Canadian scholarly societies not contracting with commercial firms. Rarely could the societies break out journal publishing (as opposed to editing) costs, given that the production and distribution of many society journals was one of many activities conducted by society office staff.

Rather than address these issues as indicative of a significant and growing flaw in the support program's structure, SSHRC soldiered on, leaving its approach and eligibility rules largely intact.

In the end, two elements rose to the fore. First, journals gained no obvious credit for their publishing success. Led by the librarians, the dominant narrative within academe focused on overpricing. Second, in Canada, with hindsight, it has become apparent that as a research funding agency, SSHRC was not mandated to be, and never saw itself as, an instrument for the development of a journal publishing sector parallel to book and magazine publishing. Rather, it was subsidizing the circulation of peer-reviewed and edited research findings by Canadians, full stop.

Lorimer, Rowland. (2020). Canadian Scholarly Journal Publishing: The Knowledge Economy Calls. Scholarly and Research Communication, 11(2): 0206361, 17 pp. 
Yet, significantly, the development of a journal publishing sector responsive to market demand and both domestic and international market opportunities was exactly what emerged in the post-World War II years in many other countries, such as the U.S., the U.K., Germany, France, and the Netherlands. A common model was for a group of scholars to found a journal, achieve market success, and then sell it to an established international academically oriented publisher, usually one based in the home country of the journal. Alternatively, by attending high-powered conferences, publishers such as Robert Maxwell would anoint leading researchers in evolving fields as editors to brandnew journals created on the spot (Bower, 1989).

\section{Disruptive technology}

The foregoing publishing and knowledge circulation success story, uncelebrated in Canada and around the world, was destined to undergo further evolution beginning in the mid-199os. Two developments converged. The first was that librarians were drawing the attention of university administrators, and academics in general, to the perceived overpricing of serials by international journal publishers. (Overpricing was not the practice for the vast majority of Canadian journals in any discipline.) The second converging element was that the internet was making possible a wholesale transformation of journal publishing from print to digital. So promising were digital information capacities, including instantaneous worldwide distribution and online manuscript handling, that calls by the librarians for dialing back price increases became calls for zero pricing.

A tipping point came in 2002 with the intervention of George Soros and his Open Society Foundation (2002). Soros convened a 16-person meeting, largely of technology enthusiasts and public-spirited academics, that published a manifesto on open access (OA), promoting the idea that open access to content, which researchers created without the expectation of recompense, was fully achievable by self-archiving and open access journals. This call for OA was magnified dramatically by Silicon Valley's own interest in promoting Stewart Brand's (Wikipedia, n.d.) phrase, "information wants to be free" (n.p.). So-called free information legitimized their hoovering up published content and monetizing its further distribution in new formats (Lanier, 2013).

\section{Open access: The second disruptor}

Currently, OA has joined with digital technology as a primary driver of change in journal publishing. However, while digital technology opens all kinds of horizons, OA focuses on the particularities of the financial management of consumption. Also, while digital processes provide a new and proven technology, OA seeks to achieve a social ideal through replacing normal user-pay capitalist practice with underwriting by stakeholder agencies - libraries, research funders and organizations, educational organizations, and society - thereby weakening the role of publishers, be they commercial operations or scholarly societies.

There is little question that the OA goal of the free, immediate, and almost universal availability of many research findings for flexible use is a social good. The circulation of knowledge and the fostering of research communities have always been the central goals of scholarly journal publishing. This is why many journal organizations around 


\section{Scholarly and Research}

\section{Communication}

VOLUME 11 / ISSUE 2 / 2020 the world, including the Canadian Association of Learned Journals (CALJ, n.d.) and an increasing number of for-profit journal publishers, have joined many academics in endorsing the principle of OA.

However, there is also little question that the pursuit of OA will deprive journal publishing of an obvious form of market dynamics that underwrite and help regulate the supply and quality of goods and services. In this regard, probably the worst OA model is the most popular: Article Processing Charges (APCs). In this model, authors or their agents pay journal publishers for publishing services for each peer-reviewed article that the journal has accepted. The closer a model gets to an article-by-article fee to publish, the greater the tension with peer review, which is the fundamental control-of-content mechanism in scholarly journal publishing. As history reveals, when the foundations of the financial management of publishing depend on editorial policy, almost by definition, the tail is certain to wag the dog.

In contrast, the closer a model gets to disinterested underwriting in which the editorial and finance departments are independent, the greater the opportunity for journals to continue their central role of vetting manuscripts for their contribution to knowledge. In turn, such unencumbered vetting maximizes the likelihood of expert assessors identifying useful research and sustaining knowledge communities - the highest-level endgoal of the journal publishing enterprise. Notably, this disinterest is a characteristic of the subscription-based funding model. It is also a world-recognized, praiseworthy feature of Canadian federal publishing support programs for both magazines and books. Luckily, in pursuit of OA, as many as 30 models that evince varying levels of disinterest are already being tried out (see Wise \& Estelle, 2019). Lisa Hinchliffe (2020) has provided a summary of the various categories of OA publishing. Also useful for understanding $\mathrm{OA}$ and its connection to digital publishing is a publicly available 37-page consultation report by the publishers Taylor \& Francis (2020) to the United Kingdom Research and Innovation Open Access Review.

The good news regarding OA development is that, as of early 2020, the OA debate has moved beyond questioning the necessity of journals and the proposition that voluntary labour by academics together with library resources can easily replace them (R. Anderson, 2020).

Other good news is that, alongside OA being embraced by both publishers and consumers of online access to journals, there has been a considerable amount of innovation in the presentation of research, largely by commercial journal publishers. Suffice it to say, the tables, figures, colour, video, sound, interactivity, and so on featured in recent articles is impressive. Notable examples include the transformation of an article into an easy-to-digest evocative presentation of a key finding (Larivière \& Sugimoto, 2018; Nature Index, 2018;) and a primer for authors and publishers on graphic design for visual science communication (Murchie \& Diomede, 2020).

In addition to innovation in the presentation of research, a derivative "meta-publishing" industry is opening up. Trackable online usage can be analyzed to inform journals of article performance and reader behaviour (see Lorimer, 2020). ResearchGate and

Lorimer, Rowland. (2020). Canadian Scholarly Journal Publishing: The Knowledge Economy Calls. Scholarly and Research Communication, 11(2): 0206361, 17 pp. 
Academia are establishing commercializing services to a) alert authors to the reception of their articles, and b) filter a reading environment for individual researchers. As well, Digital Science, a commercial initiative owned by the large publisher Holtzbrinck, has already developed extensive alternative usage metrics (altmetrics) to provide guidance on community attention given to an article. Cleverly, Digital Science has created a logo that journals are encouraged to display on the first page of each article. But they have gone far beyond this basic service. Digital Science (2020) illustrates how large companies can create new products for emerging research information markets that capture even larger swaths of institutional resources than those they earn from journal publishing. They have mined the vast and disparate elements of the information systems in the research and education sector and created readily accessible databases that report on seemingly every element of research activity, from grant programs and grant proposals to awarded grants, reports, articles datasets, and so forth.

Other commercial publishing firms illustrate how to provide a much-appreciated service and consolidate goodwill by creating free, highly engaging public information initiatives that highlight journal content. (See, for example, Nature Briefing [2020] and associated podcasts and Canadian Science Publishing's [2020b, 2020c] research blogs and briefs.)

\section{Canadian journal publishing in this developing milieu}

In the current context, SSHRC's long-term Aid to Scholarly Journals program continues to be valuable for its delivery of support to some journals. It can serve as a building block for a vibrant Canadian journal publishing sector, but for that to happen, its support must build on the strengths and contributions of established and respected Canadian journals.

SSHRC's aid program is focused on editing, whereas the world and technology have moved on to a publishing model in which editing is a key but not an all-encompassing component. SSHRC's program limits funds to a below-market amount (no more than $\mathrm{CDN} \$ 1,050$ per article) for peer-reviewed article publication and the transition to OA, but it provides nothing for notes, reviews, digests, sales and marketing, unreviewed commentary, retractions, professional development, joint projects, or any other knowledge-and-community-building elements. It also requires applicants to endorse an intention to transition to 12-month delayed open access. And there is always the possibility of more radical restrictions in future SSHRC policy (e.g., immediate OA requirements without compensatory funding).

In the design of its eligibility criteria, SSHRC's aid program puts at risk or directly undermines a good chunk of market earnings of internationally established Canadian journals because usage in the first 12 months represents a very small percentage of usage value, most likely less than 10 percent. It is not unusual for social sciences and humanities journal articles to be heavily used for over a decade, with usage tailing off over the next decade (Lorimer, 2020). In exchange, it offers journals a chance, but not a guarantee, of an annual grant renewable by application every three years for a maximum of $\mathrm{CDN} \$ 30,000$, which is often discounted on the recommendation of academic subject-matter-oriented - and often publishing-naïve - peer-review committees.

Lorimer, Rowland. (2020). Canadian Scholarly Journal Publishing: The Knowledge Economy Calls. Scholarly and Research Communication, 11(2): 0206361, 17 pp.
Scholarly and Research

Communication

VOLUME 11 / ISSUE 2 / 2020

derivative "metapublishing" 
Scholarly and Research

\section{Communication}

VOLUME 11 / ISSUE 2 / 2020
The one move that SSHRC might claim as addressing publishing dynamics was its decision to offer journals the opportunity to redirect financial support to an independent "platform." The one platform (of four deemed eligible) that decided to participate focuses solely on the production technology and relationships needed to make peerreviewed OA content available.

The term "platform" is a relatively new, ambiguous naming of the provision of a partial set of publishing services. At minimum it is the gathering together of a group of journals or, in general, digital content and associated digital services, at a single site with the intent that such a conglomeration makes access easier and more frequent.

Whether the funding of this platform is a net gain for journals is an open question, in part because there is no public information regarding its performance. To act as a development vehicle, any platform needs to offer journals guarantees or estimates of usage to be gained. On the publishing side of the equation, it needs to take into account a realistic financial model for replacing journal subscription income, adopt an overall strategy to position individual titles and the collection as a whole in their various target markets, and seek out collaborative opportunities to work with journals to create loyal author and reader communities. Its challenge is to move from conjectural to evidencebased success. Its road to success must be paved with journal-based business development that embraces a full publishing palate of organizational, financial, professional, and technological opportunities.

\section{Canada's publishing achievements and their social implications}

As noted at the outset of this paper, the federal government currently supports a host of book and magazine publishing firms that serve a multitude of reading publics in the name of cultural development; this is currently administered through the department of Canadian Heritage. With federal support in place, all but a few provinces boast support for magazine and book titles.

In the magazine sector, Canada has produced international innovators who have commanded the highest ranks of magazine professionals around the world. Canadian magazines have also found ways of successfully operating in small markets. Some have reached international markets. In addition to the federal and provincial governments, many municipalities support various types of magazines for reasons of cultural and local dynamism.

Book publishing tells a parallel success story. Canadian authors have been short-listed for the world's most prestigious literary and subject-oriented book prizes. Margaret Atwood is and Michael Ondaatje was, the reigning queen and king. Canada's smallfirm-dominated book publishing community has an international reputation, the Canadian marketplace boasts the continuing presence of books on all manner of subjects, and Canadian titles enjoy success in foreign markets, including the U.S. and international rights sales. This is not to say that Canadian book publishing is an unqualified success. A 2018 report entitled "More Canada: Increasing Canadians' Awareness and Reading of Canadian Books" (Canadian Publishers Hosted Software Solutions, 2018) indicates that the domestic market share for Canadian titles has diminished dramatically over the past few decades. 
Notwithstanding such difficulties, these successes have resulted in a host of career opportunities for young people to launch new and exciting titles at home and abroad. The book and magazine publishing industries make public the frontiers of ideas, realities, and current concerns. The country's many publishing initiatives provide both the personal satisfaction of meaning making and the opportunity to hone professional skills and judgment. They provide a base for participants to expand their horizons through joining larger enterprises, institutions, organizations, and movements - all of which need new, realistic publishing-based actions and proposals to maintain their preeminence and develop new products and markets.

Both industries contribute not only to significant, personally meaningful opportunities that help young people transition to a working life, they also contribute to the social and cultural capital of the nation and, as a result, Canada's international status and economic health. Further, these publishing firms are members of the growing creative sector that is an accepted bulwark of modern developed economies in a climate-constrained world. They allow young people to experience the discipline of the marketplace with manageable consequences.

Two conceptual frameworks that speak to the above dynamics are worthy of attention. The first is the generation of social capital and the capture of community value via social relationships (see, for example, Putnam, 2000). The second relates to efforts that are not directed at economic growth but rather human betterment, a term that, in its most general sense, means that society is better off (see Boulding, 1971). Human betterment is receiving greater attention in the face of climate deterioration. It is also bound to receive increased attention in the aftermath of the COVID-19 pandemic. In concrete terms, the purpose of social capital and human betterment activities is to promote social development and cohesion broadly defined.

\section{Extending policy success to journal publishing}

The above dynamics can be replicated in Canadian journal publishing. The natural home for such a program is alongside book and magazine development programs in the Department of Canadian Heritage (DCH). Parallel to DCH's relationship with the Canada Council for the Arts, it might be possible for complementary programs to exist in DCH and SSHRC, and indeed, DCH and Canada's science research funders.

Setting up such a program is not a slam dunk. After all, it took over 15 years to establish a successful and stable book publishing industry development program. But the government is far more experienced in these matters than it was in the early 1970 .

Journal publishing arose from a perceived demand to share in the results of such luminaries as Erasmus Darwin and his fellow empirical philosophers, who were in a position to undertake research that led to the industrial revolution (Uglow, 2002). As time went on, journals came to rely on those who wished to spread the word and had a talent for reviewing, producing, and disseminating research reports. By the twentieth century, scholarly journals were headed up by successions of recognized scholars, featured contributions from members of a discipline or field, and, increasingly, employed a staff of women editors - often senior students and early career researchers - with writing and editing talent.

Lorimer, Rowland. (2020). Canadian Scholarly Journal Publishing: The Knowledge Economy Calls. Scholarly and Research Communication, 11(2): 0206361, 17 pp. 


\section{Scholarly and Research}

\section{Communication}

VOLUME 11 / ISSUE 2 / 2020

Scholarly journal publishing has become a recognized profession.
By the time the twentieth century passed, journals had come to operate with a team of professionals managing the flow of manuscripts and peer reviews; copy editing, laying out, and proofreading accepted articles and budgeting; recasting meta-data elements such as keywords, titles, and abstracts; making decisions on non-textual elements such as illustrations, overview diagrams, and interactivity with data; working with persistent identifiers for people and things; developing best practices for access while maintaining revenue; maintaining currency with emerging data policies and practices; managing relations with publishing partners; maintaining the technical and aesthetic elements of a journal's website; taking advantage of evolving external content enhancement services; gaining access to usage data and analytics, and managing its dissemination; undertaking software evaluation; and so forth. Kent Anderson's (2018) list of "things publishers do" surpasses 100 items.

In the U.K., Europe, and the U.S., to say nothing about Latin America, India, and China, scholarly journal publishing has become a recognized profession. Associations exist that boast a high percentage of practitioners as members. They hold annual conferences to share expertise in the many different activities undertaken by publishers and to keep abreast of innovations emerging within and outside the industry. These journal publishers generate a considerable number of jobs that evolve into professional careers and contribute to sustaining knowledge communities, social capital, and human betterment. Their success appears largely attributable to the existence of large firms that retain earnings that are sufficient to collaborate with their peers to underwrite the continual professional development of their employees and to share perceptions of possible developments.

Canada has largely been sidelined from these dynamics by the lack of a group of large firms with sufficient resources to gain recognition for journal publishing as a profession, fund conferences, and foster the development of an industry policy. Canada's two main journal publishers, Canadian Science Publishing and the University of Toronto Press, fulfil their professional needs by going to Europe and the U.S. for conferences. No doubt there are a few other journal publishers, in areas such as health, that also find their way to such conferences. But the degree to which their gains are transferred to smaller Canadian operations is limited.

The venue for that transfer is the annual conference of the Canadian Association of Learned Journals (CALJ). There are over 600 journal titles in Canada, yet CALJ only has between 100 and 150 members (Ulrich's Periodicals Directory, 2020). At its annual conference, it is lucky to attract 30 members. There are two reasons for this. First is the cost of travel and accommodation. Journals are run on a shoestring not-for-profit model, and the revolving door of editors and the teams they assemble for their short terms lack the budget for it. SSHRC's per-article support of CDN\$1,050 does not begin to cover such professional development. The other is that generally speaking, only journals that earn substantial subscription-based revenues employ workers who see themselves as current or potential members of a profession. In other journals, and especially in OA journals, those contributing labour hours see themselves as taking on tasks "they are good at" for a limited term.

Lorimer, Rowland. (2020). Canadian Scholarly Journal Publishing: The Knowledge Economy Calls. Scholarly and Research Communication, 11(2): 0206361, 17 pp. 
These are not, however, inevitable realities. They are indicators of the need for determined public investment alongside a commitment on behalf of current publishers to lay the foundations for industry development.

Canada is fully capable of having a journal publishing sector equal in weight and status to our hefty research industry. CALJ (2017) made an attempt to encourage such developments with a call for the establishment of a Journal Impact and Innovation Fund. It fell on deaf ears. So intent was the Canadian post-secondary education sector on saving money - it was (and still is) refusing to pay reprographic rights to authors and publishers - that the librarians merely nodded. The universities, it appears, were convinced they were going to be handed professionally published journal articles on a costless OA platter (alongside their self-claimed unfettered educational user rights). In addition, federal support programs in the research and education sectors for the operational funding of ongoing initiatives such as journal publishing were and are non-existent. The closest agency, the Canada Foundation for Innovation, pursues ever-novel innovations, rather than operating budgets for new critical infrastructure designed to respond to digital opportunities.

The opportunities inherent in Canadian scholarly journal publishing, especially at a time when the activities intrinsic to its operations are quickly becoming more extensive, more complex, and far more capable of making a contribution to Canada's interests, are powerful and exciting. The opportunities of a modern knowledge and information economy can best be seized by replacing the subsidization of editing with public investment in sector development to reap the successes of book and magazine publishing policies. The potential rewards are Canada's full participation in a global knowledge industry, Canadians establishing careers in the industry, the encouragement of entrepreneurship in spin-off industries, and a more robust net-zero contribution to global social capital and human betterment.

\section{References}

Acheson, Keith, \& Maule, Christopher. (2000). Rethinking Canadian magazine policy. Gazette, 62(3-4), 205-229. doi: 10.1177/0016549200062003003

Anderson, Kent. (2018). Focusing on value - 102 things journal publishers do (2018 update). URL: https://scholarlykitchen.sspnet.org/2018/02/06/focusing-value-102-things-journal-publishers -2018-update/ [Accessed between February 1-June 11, 2020].

Anderson, Rick. (2020). Will the future of scholarly communication be pluralistic and democratic or monolithic and authoritarian? The Scholarly Kitchen. URL: https://scholarlykitchen.sspnet.org /2020/02/25/will-the-future-of-scholarly-communication-be-pluralistic-and-democratic -or-monolithic-and-authoritarian/?informz=1 [Accessed between February 1-June 11, 2020].

Association of Canadian Publishers. (1991). Book publishing and Canadian culture: A national strategy for the 1990s. Toronto, ON: ACP.

Association of Canadian Publishers. (1985). A mid-decade assessment. Toronto, ON: ACP.

Association of Canadian Publishers. (1980). Canadian publishing: An industrial strategy for its preservation and development in the eighties. Toronto, ON: ACP.

Boulding, Kenneth. 1971. The meaning of human betterment. Nebraska Journal of Economics and Business, 10 (2) 3-12. URL: https://www.jstor.org/stable/40472383 [Accessed between February 1June 11, 2020].
Scholarly and Research Communication

VOLUME 11 / ISSUE 2 / 2020

Call for a journal publishing sector equal in weight and status to Canada's hefty research industry. 


\section{Scholarly and Research Communication}

VOLUME 11 / ISSUE 2 / 2020
Bower, Tom. (1989). Robert Maxwell: The outsider. London, UK: Aurum Books.

Canada. (1961). Report of the Royal Commission on periodicals. Ottawa, ON: Queen's Printer.

Canada. (1952). Royal Commission on national development in the arts, letters and sciences. Ottawa, ON: King's Printer.

Canadian Association of Learned Journals. (2017). Innovation, discoverability, and impact in journal publishing: A proposal for a Journal Impact and Innovation Fund. URL: https://www.calj-acrs.ca /sites/default/files/calj_journal_impact_and_innovation_fund_july_2017_en_1_o.pdf [Accessed between February 1-June 11, 2020].

Canadian Association of Learned Journals. (n.d). Position paper on journal open access policies. URL: https://www.calj-acrs.ca/open-access-policy [Accessed between February 1-June 11, 2020].

Canadian Journal of Communication. (1997). Scholarly communication in the next millennium: Selected papers from Canada's policy conference, 22(3). URL: https://www.cjc-online.ca/index.php /journal/issue/view/82/showToc [Accessed between February 1-June 11, 2020].

Canadian Science Publishing. (2020a). Our history. URL: https://www.nrcresearchpress.com/page /about/ourhistory [Accessed between February 1-June 11, 2020].

Canadian Science Publishing. (202ob). All topics. URL: http://blog.cdnsciencepub.com/all-topics/ [Accessed between February 1-June 11, 2020].

Canadian Science Publishing. (2020c). Brief. URL: http://blog.cdnsciencepub.com/type/brief/ [Accessed between February 1-June 11, 2020].

Canadian Publishers Hosted Software Solutions. (2018). More Canada: Increasing Canadians' awareness and reading of Canadian books. Halifax, NS: Formac.

Digital Science. (2020). Home. URL: https://www.digital-science.com/ [Accessed between February 1June 11, 2020].

Hinchliffe, Lisa. (2020). Seeking sustainability: Publishing models for an open access age. URL: https:// scholarlykitchen.sspnet.org/2020/04/o7/seeking-sustainability-publishing-models-for-an-open -access-age/?informz $=1$ [Accessed between February 1-June 11, 2020].

Lanier, Jeron. (2013). Who owns the future? Toronto, ON: Simon and Schuster.

Larivière, Vincent, \& Sugimoto, Cassidy. (2018). The journal impact factor: A brief history, critique, and discussion of adverse effects. In W. Glänzel, H.F. Moed, U. Schmoch, \& M. Thelwall. (Eds.), Springer handbook of science and technology indicators. Cham, CH: Springer International Publishing. URL: https://arxiv.org/ftp/arxiv/papers/1801/1801.08992.pdf [Accessed between February 1-June 11, 2020].

Litvak, I.A., \& Maule, C.J. (1980/1981). Bill C-58 and the regulation of periodicals in Canada. International Journal, $36(1), 70-90$.

Lorimer, Rowland. (2012). Ultra libris: Policy, technology and the creative economy of book publishing in Canada. Toronto, ON: ECW Press.

Lorimer, Rowland. (2020). Article usage analytics for the Canadian Journal of Communication 20152018: A guide for authors, publishers, and readers. Canadian Journal of Communication, 45(1) 157-171. doi: 10.22230/cjc.2020v45n1a3765

Murchie, Karen J., \& Diomede, Dylan. (2020). Fundamentals of graphic design—essential tools for effective visual science communication. FACETS, 5 (1) 409-422. doi: 10.1139/facets-2018-0049

National Research Council. (2009). 1924 to 2009: History of the NRC Canada Institute for Scientific and Technical Information. URL: https://nrc-publications.canada.ca/eng/view/accepted/?id= cod7ec74-40af-4460-8a1b-bd5ec592127b [Accessed between February 1-June 11, 2020].

Nature Index. (2018). What's wrong with the journal impact factor in five graphs. URL: https://www. natureindex.com/news-blog/whats-wrong-with-the-jif-in-five-graphs [Accessed between February 1-June 11, 2020].

Lorimer, Rowland. (2020). Canadian Scholarly Journal Publishing: The Knowledge Economy Calls. Scholarly and Research Communication, 11(2): 0206361, 17 pp. 
Nature Research. (2020). Nature briefing. URL: https://us17.campaign-archive.com/?u=2c6057c528fd c6f 73 fa196d9d\&id=1ea97fb35e\&e=351a3foc9d [Accessed between February 1-June 11, 2020].

Ontario. Royal Commission on Book Publishing. (1972). Canadian publishers and Canadian publishing. Toronto, ON: Queen's Printer.

Ontario. Royal Commission on Book Publishing. (1971). Background papers. Toronto, ON: Queen's Printer.

Open Society Foundation. (2002). Budget open access initiative. URL: https://www.budapestopenaccessinitiative.org/read [Accessed between February 1-June 11, 2020].

Putnam, Robert D. (2000). Bowling alone: The collapse and revival of American community. New York, NY: Simon \& Schuster.

Taylor \& Francis. (2020). Taylor \& Francis input to UKRI open access review. URL: https://newsroom. taylorandfrancisgroup.com/wp-content/uploads/2020/o6/Taylor-Francis-input-to-UKRI-Open -Access-Review.pdf [Accessed between February 1-June 11, 2020].

Uglow, Jenny. (2002). The lunar men: The friends who made the future. London, UK: Faber and Faber. Ulrich's Periodicals Directory. (2020). Login. URL: http://ulrichsweb.serialssolutions.com/login

[Accessed between February 1-June 11, 2020].

VanBuskirk, Mary. (2009). Commemorative booklet. Ottawa, ON: NRC.

Wikipedia. (n.d.). Information wants to be free. URL: https://en.wikipedia.org/wiki/Information _wants_to_be_free. [Accessed between February 1-June 11, 2020].

Wise, A., \& Estelle, L. (2019). Society publishers accelerating open access and Plan S - final project report. Figshare. doi: 10.6084/m9.figshare.9805007.v1 [Accessed between February 1-June 11, 2020].
Scholarly and Research

Communication

VOLUME 11 / ISSUE 2 / 2020

Lorimer, Rowland. (2020). Canadian Scholarly Journal Publishing: The Knowledge Economy Calls. Scholarly and Research Communication, 11(2): 0206361, 17 pp. 